\title{
PELAKSANAAN PEMBERIAN REWARD DAN PUNISHMENT DALAM PEMBELAJARAN PAI DI SIMA NEGERI 13 MAKASSAR
}

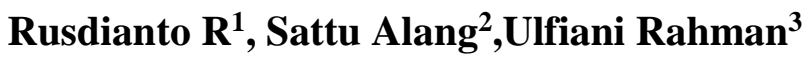 \\ Universitas Islam Negeri Alauddin Makassar
}

\begin{abstract}
This study aims to understand the process of giving rewards and punishments in Islamic education learning at SMA Negeri 13 Makassar. This type of research is a qualitative research with a phenomenological approach. Sources of research data are the vice principal, teachers and students. The data methods used were interviews, observation and documentation. The technique of processing and analyzing data is carried out in three stages, namely: data reduction, data presentation, and drawing conclusions. These results indicate that the awarding at SMA Negeri 13 Makassar is mostly in the form of praise and added grades, while for the punishment varies in form, some punishments are given in the form of adding assignments, offering warnings, to involving parents. However, most forms of punishment involve additional duties. Supporting factors that provide rewards at SMA Negeri 13 Makassar are the authority of teachers in organizing the reward, the support of the school and parents and the motivation of students. Supporting factors are namely the support of the school and parents and the awareness of students. Inhibiting factors for rewards are namely costs, environment and different levels of students. Penalty inhibiting factors are based on the attention of parents, the existence of human rights and the diverse character of students. The results of the researcher's analysis are offering rewards and punishments that can increase students' learning motivation, student learning achievement and can improve student behavior.
\end{abstract}

Keywords: Reward, Punishment

\section{PENDAHULUAN}

Setiap peserta didik membutuhkan penguatan dalam belajar karena penguatan merupakan penghargaan yang dapat menimbulkan dorongan dan semangat dalam belajar sehingga akan membuat prestasi belajarnya meningkat. Jadi, jika dijabarkan fungsi penguatan untuk memberikan ganjaran kepada peserta didik sehingga akan berbesar hati dan meningkatkan partisipasinya dalam setiap proses pembelajaran. Diharapkan peserta didik dapat meningkatkan perhatian, menumbuhkan dan mempertahankan motivasi belajar serta menyenangi mata pelajaran yang diberikan oleh guru, sehingga prestasi belajarnya juga diharapkan dapat meningkat. Demikian karena sifat dasar manusia akan merasa senang bila mendapatkan hadiah dan pujian, maka jika hatinya senang, ia akan lebih bersemangat dalam belajar.

Pemberian reward dan punishment dalam pembelajaran merupakan salah satu usaha yang dilakukan oleh guru dengan maksud untuk menjadikan peserta didik lebih giat lagi dalam melakukan sesuatu guna memperbaiki atau mempertahankan prestasi yang 
telah dicapainya. ${ }^{1}$ Pemberian hukuman atau punishment dalam pembelajaran bertujuan untuk merubah dan memotivasi peserta didik sehingga peserta didik berlomba lomba untuk menjauhi hukuman yang sudah di tentukan terlebih dahulu. Selain metode hukuman, pemberian hadiah atau reward juga diakui dalam dunia pendidikan. Hadiah merupakan bentuk motivasi sebagai penghargaan atas perilaku yang sesuai. Pemberian hadiah ini bertujuan untuk memberikan penguatan (reinforcement) terhadap perilaku yang baik. Sehingga akan memotivasi peserta didik dalam proses pembelajaran.

SMA Negeri 13 Makassar adalah salah satu lembaga pendidikan Formal yang berada di Kota Makassar. Berdasarkan hasil observasi awal pada 11 Januari 2019, para pendidik di SMA Negeri 13 Makassar belum terlalu menerapkan reward and punishment. Pada saat proses pembelajaran peserta didik diberikan hadiah berupa pujian ketika mampu menjawab pertanyaan dari guru. Namun, pada saat pembelajaran masih ada saja peserta didik yang ribut dan bolos pada saat pembelajaran bahkan mereka tidak hadir di sekolah. Pada jam pertama masih ada peserta didik yang terlambat dan tidak masuk belajar. Karena faktor malas masuk belajar, nilai yang tidak tuntas maka ada peserta didik yang tidak naik kelas. Mereka sudah diberikan hukuman tetapi belum juga berubah peserta didik tersebut.

Berdasarkan latar belakang di atas, maka tujuan penelitian ini adalah untuk mengetahui Pelaksanaan Pemberian Reward dan Punishment dalam Pembelajaran PAI di SMA Negeri 13 Makassar.

\section{METODE PENELITIAN}

Jenis penelitian ini adalah penelitian kualitatif bersifat fenomonologi. Penelitian kualitatif adalah penelitian yang menghasilkan data deskriptif berupa kata-kata tertulis dari orang-orang, fenomena, peristiwa, aktivitas sosial, sikap, kepercayaan, persepsi dan pemikiran orang secara individual atau kelompok. ${ }^{2}$

Penelitian ini tergolong jenis penelitian yang bersifat kualitatif deskriptif. karena penelitian ini memberikan gambaran tentang hasil penelitian dengan mendeskripsikan data aktual yang diperoleh di lapangan. Penelitian ini akan mendeskripsikan objek secara alamiah yaitu pelaksanaan pemberian reward dan punishment dalam pembelajaran PAI di SMA Negeri 13 Makassar.

Langkah awal yang harus ditempuh oleh seorang peneliti untuk mengkaji adalah menentukan pendekatan. Pendekatan yang dimaksud di sini menjelaskan perspektif yang

\footnotetext{
${ }^{1}$ Dewi Yana dkk, "Pemberian Reward and Punishment sebagai Upaya Meningkatkan Prestasi Peserta didik Kelas V di SDN 15 Lhokseumawe", Jurnal Ilmiah FKIP Unsyiah I, no. 2 (2016): h.11.

${ }^{2}$ Syaodih Sukmadinata, Metode Penelitian Pendidikan (Cet. VIII; Bandung: PT. Remaja Rosdakarya, 2012), h. 60.
} 
digunakan dalam membahas objek penelitian ${ }^{3}$. Pendekatan studi yang dimaksud disini menjelaskan perspektif yang digunakan dalam membahas objek penelitian, yaitu disiplin ilmu yang menjadi acuan bagi peneliti dalam melakukan penelitian, adapun pendekatan studi keilmuan yang dianggap relevan dengan judul yang dibahas adalah pendekatan interdisipliner yaitu pendekatan pedagogis dan psikologis. ${ }^{4}$

Sumber data dalam peneltian ini adalah wakil kepala sekolah, guru PAI dan peserta didik. Metode pengumpulan data yang digunakan dalam penelitian ini adalah observasi, wawancara, dan dokumentasi. Teknik pengolahan dan analisis data dalam penelitian ini dilakukan melalui tiga tahapan secara berkesinambungan, yaitu mereduksi data, penyajian data dan penarikan kesimpulan. Selanjutnya adalah pengujian keabsahan data. Menguji keabsahan data dalam penelitian kualitatif meliputi uji, credibility (Validitas internal), transferability (validitas eksternal), dependability (reliabilitas), dan confirmability (objektivitas). Dalam menguji keabsahan data peneliti menggunakan teknik triangulasi, yaitu teknik pemeriksaan keabsahan data yang memanfaatkan hal-hal di luar data untuk menguji kevalidan data yang telah didapat. Peneliti memeriksa keabsahan data dengan membanding kan data hasil wawancara dengan data hasil observasi.

\section{KAJIAN TEORI}

\section{A. Pengertian Reward}

Reward artinya ganjaran, hadiah, penghargaan atau imbalan. ${ }^{5}$ Istilah reward $=$ tsawab atau ganjaran didapatkan dalam al-Qur'an yang menunjukkan apa yang di perbuat oleh seseorang dalam hal ini kebiasaan anak dan remaja di kehidupan ini. Allah swt. berfirman dalam QS. ali Imran/3: 148:

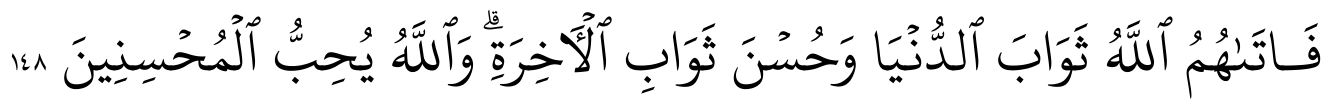

Terjemahannya:

Maka Allah memberi mereka pahala di dunia dan di akhirat. Dan Allah mencintai orangorang yang berbuat kebaikan. ${ }^{6}$

${ }^{3}$ Tim Penyusun Pedoman Penulisan Karya Ilmiah, Pedoman Penulisan Karya Tulis Ilmiah; Makalah, Skripsi, Tesis, Disertasi dan Laporan Penelitian (Cet I; Makassar: Alauddin Press, 2013), h. 16.

${ }^{4}$ Tim Penyusun Pedoman Penulisan Karya Ilmiah, Pedoman Penulisan Karya Tulis Ilmiah; Makalah, Skripsi, Tesis, Disertasi dan Laporan Penelitian, h. 16.

${ }^{5}$ Sulyadi, "Upaya Meningkatkan Disiplin Guru Dalam Kehadiran Mengajar Dikelas Melalui Penerapan Reward And Punishment di SDN 03 Simpang Kabupaten Pesisir Selatan", Jurnal Manajemen Pendidikan 3, no. 2 (2018): h. 300.

${ }^{6}$ Kementerian Agama R.I., Al-Qur`an dan Terjemahnya (Jakarta: Direktorat Jenderal Bimbingan Masyarakat Islam, 2012), h. 68. 
Penggunaan kata ini dalam bahasa Arab, reward (ganjaran) diistilahkan dengan kata "tsawab". Kata ini banyak ditemukan dalam al-Qur'an, khususnya ketika membicarakan tentang apa yang akan diterima oleh seseorang, baik di dunia maupun akhirat dari amal perbuatannya. Kata "Tsawab" selalu diterjemahkan kepada balasan yang baik. Kata "tsawab" identik dengan ganjaran yang baik seiring dengan hal ini, makna yang dimaksud dengan kata "tsawab" dalam kaitannya dengan pendidikan Islam adalah pemberian ganjaran yang baik terhadap perilaku baik dari peserta didik.

Prinsip Pemberian Reward

Pada saat memberikan hadiah atau penghargaan, ada beberapa prinsip yang harus diperhatikan oleh para pendidik. ${ }^{7}$ Diantaranya:

1. Penilaian didasarkan pada perilaku bukan pelaku.

2. Pemberian hadiah atau penghargaan harus ada batasnya.

3. Dimusyawarahkan kesepakatannya.

4. Distandarkan dari pada proses bukan hasil.

\section{B. Pengertian Punishment}

Hukuman menurut bahasa berasal dari bahasa Inggris, yaitu dari kata "Punishment" yang berarti "Law" (hukuman) atau siksaan. ${ }^{8}$ Punishment dalam bahasa Indonesia berarti Hukuman. Hukuman ialah penderitaan yang diberikan atau ditimbulkan dengan sengaja oleh seseorang (orang tua, guru) sesudah terjadi sesuatu pelanggaran, kejahatan atau kesalahan. ${ }^{9}$ Hukuman bisa juga diartikan sebagai ganjaran. Ketika Peserta didik membuat kesalahan maka bias diberikan ganjaran sesuai kesalahannya.

Oleh karena itu, pemberian ganjaran tidak serta merta sebagai suatu tindakan balas dendam antara guru dan peserta didik yang tidak bisa mencapai harapan yang diinginkan, namun guru harus memahami segala bentuk prinsip-prinsip pemberian ganjaran sebagai sanksi kependidikan. Punishment hampir sama dengn reward. Bedanya jika reward bisa berwujud benda sedangkan punishment lebih kepada ucapan.

Menurut Kamus Besar Indonesia, hukuman adalah peraturan yang dibuat oleh satu kekuasaan atau adat yang dianggap berlaku oleh dan untuk orang banyak. Artinya bahwa ganjaran suatu aturan yang dibuat untuk mengatur pergaulan hidup dalam hal ini pergaulan hidup peserta didik yang berada disekolah. ${ }^{10}$

Punishment (Hukuman) dalam bahasa Arab diistilahkan dengan 'Iqab. Al-Qur'an memakai kata 'Iqab sebanyak 20 kali dalam 11 surat. Bila memperhatikan masing-masing

\footnotetext{
${ }^{7}$ Wolfok. Teknologi Pembelajaran Landasan dan Aplikasinya. (Yogyakarta: Pustaka Pelajar, 2009), h. 192.

${ }^{8}$ John M. Echols dan Hasan Shadily, Kamus Inggris Indonesia (Jakarta: Gramedia, 2014), h. 456.

${ }^{9}$ Umy Kusyairy dan Sulkipli, "Meningkatkan Hasil Belajar Peserta Didik Melalui Pemberian Reward And Punishment", Jurnal Pendidikan Fisika 6, no. 2 (2018): h. 83.

${ }^{10}$ Umy Kusyairy dan Sulkipli, "Meningkatkan Hasil Belajar Peserta Didik Melalui Pemberian Reward And Punishment", Jurnal Pendidikan Fisika 6, no. 2 (2018): h. 83.
} 
ayat tersebut terlihat bahwa kata 'Iqab mayoritasnya didahului oleh kata syadiid (yang paling, amat dan sangat). Dan kesemuanya menunjukkan arti keburukan dan adzab yang menyedihkan. ${ }^{11}$ Allah swt. Berfirman dalam QS. Ali Imran/3: 11:

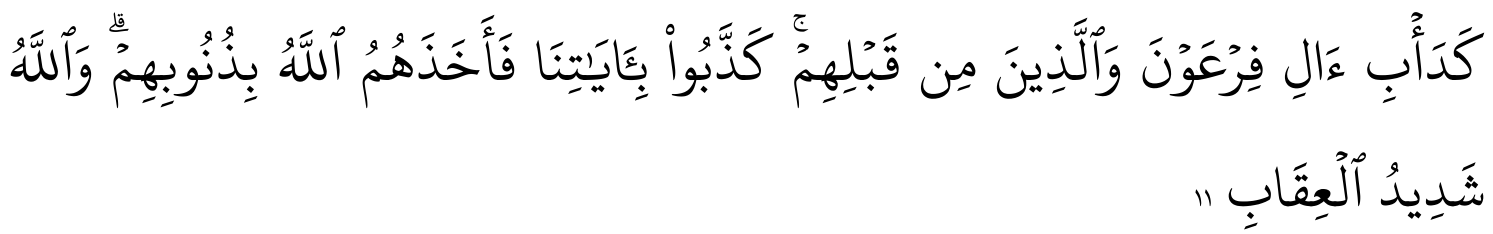

Terjemahannya:

(keadaan mereka) adalah sebagai keadaan kaum Fir'aun dan orang-orang yang sebelumnya; mereka mendustakan ayat-ayat Kami; Karena itu Allah menyiksa mereka disebabkan dosa-dosa mereka. dan Allah sangat keras siksa-Nya. ${ }^{12}$

Dari ayat di atas dapat dipahami bahwa kata 'Iqab ditujukan kepada balasan dosa sebagai akibat dari perbuatan jahat manusia. Dalam hubungannya dengan pendidikan Islam, 'Iqab diartikan sebagai alat pendidikan preventif dan refresif yang paling tidak menyenangkan serta balasan dari perbuatan yang tidak baik yang dilakukan peserta didik. Bila terpaksa, berilah hukuman yang mendidik, tidak menyakiti badan dan jiwa. Hukuman itu harus adil (sesuai dengan kesalahan). Anak harus mengetahui mengapa ia dihukum. Selanjutnya, hukuman itu harus membawa anak kepada kesadaran akan kesalahannya. Hukuman jangan sampai meninggalkan dendam pada anak. Yang akan disoroti berikutnya adalah perilaku, kebanyakan orang tua di rumah dalam memberikan hukuman.

Adapun prinsip-prinsip punishment yaitu

1. Prinsip Psikolgi (kejiwaan)

2. Prinsip keadilan

3. Prinsip Kasih Sayang

4. Prinsip keharusan atau keterpaksaan

Upaya pengembangan nilai, moral dan sikap juga diharapkan dapat dikembangkan secara efektif di lingkungan sekolah/madrasah. Akhir-akhir ini, karena semakin maraknya perilaku remaja dalam hal ini adalah peserta didik SMA yang kurang menjunjung tinggi nilai-nilai, moral, dan sikap positif maka diberlakukan lagi pendidikan budi pekerti di sekolah. Penentuan kelulusan peserta didik tidak hanya didasarkan pada prestasi akademik belaka melainkan harus dikaitkan dengan budi pekerti peserta didik tersebut. Proses pendidikan budi pekerti meskipun zaman sebelumnya sudah diterapkan di sekolah, namun kemudian menghilang begitu saja seiring dengan gencarnya kampanye mengejar dalam pembangunan teknologi Pendidikan budi pekerti ini sampai sekarang

\footnotetext{
${ }^{11}$ Halim Purnomo dan Husnul Khotimah Abdi, Model Reward dan Punishment Perspektif Pendidikan Islam, h. 2.

${ }^{12}$ Kementerian Agama R.I., Al-Qur`an dan Terjemahnya, h. 51.
} 
masih dalam proses penyempurnaan untuk kemudian menunggu hasilnya untuk dievaluasi.

\section{HASIL PENELITIAN DAN PEMBAHASAN}

\section{A. Proses Pemberian Reward dan Punishment dalam Pembelajaran PAI di SMA Negeri 13 Makassar}

\section{Perencanaan Pemberian Reward dan Punishment dalam Pembelajaran PAI di SMA Negeri 13 Makassar}

Pemberian Reward dan punishment merupakan salah satu cara yang dilakukan oleh guru untuk meningkatkan motivasi belajar atau hasil belajar peserta didik di SMA Negeri 13 Makassar. Untuk mencapai hal tersebut, maka dibutuhkan langkah operasional yang tertib sebagai bagian yang tidak terpisahkan dari sistem persekolahan yang berlaku dan dihayati oleh seluruh komponen yang terlibat sebagai kewajiban yang perlu dipatuhi dan akan dikenai sanksi-sanksi jika terjadi penyimpangan.

Penjabaran langkah operasional tertib itu diwujudkan dalam tata tertib Peserta Didik selaku ketentuan-ketentuan yang mengatur kehidupan sekolah sehari-hari dan mengandung sanksi terhadap pelanggarannya. Bagi para peserta didik, tata tertib peserta didik mengatur kehidupan sekolah yang bersifat wajib dipatuhi. Kewajiban mematuhi tata tertib akan menjadi kebanggaan setiap peserta didik, sedangkan pelanggaran terhadapnya akan merusak citra bahkan menanggalkan kedudukannya sebagai peserta didik.

Oleh karena itu, untuk membangun kesadaran peserta didik agar selalu patuh dan taat terhadap tata tertib sekolah, maka dalam proses belajar mengajar diterapkan reward dan punishment. Guru akan mengacu kepada tata tertib ketika merencanakan pemberian reward dan punishment dalam pembelajaran. Hal itu di ungkapkan oleh wakil kepala sekolah bidang kurikulum, beliau berkata:

Berbicara masalah aturan, setiap guru dan sekolah memiliki aturan masing-masing. untuk menjalankan reward dan punishment, guru dan sekolah memiliki langkahlangkah dan aturan sendiri. Namun guru tetap mengacu pada tata tertib sekolah ketika merencanakan atau menerapkan reward dan punishment. ${ }^{13}$

Mengenai perencanaan reward dan punishment, pihak sekolah memiliki aturanaturan secara umum melalui tata tertib yang selanjutnya diterapkan oleh guru dalam rangka membangun suasana belajar yang baik untuk mencapai tujuan belajar yang dicitacitakan. Melalui aturan sekolah, para guru tetap mendapatkan pengawasan saat melaksanakan reward dan punishment. Pihak Sekolah memberikan kesempatan bagi guru memilih bentuk reward dan punishment selama tidak keluar dari koridor-koridor yang telah ditentukan pihak sekolah yang tertuang dalam aturan sekolah mengenai pemberian reward dan punishment.

${ }^{13} \mathrm{Hj}$. Nursyamsiah (52 Tahun) Wakil Kepala Sekolah Bidang Kurikulum SMA Negeri 13 Makassar, Wawancara, Makassar 24 Juni 2019 
Adapun langkah-langkah perencanaan guru dalam pemberian reward dan punishment yang SMA Negeri 13 Makassar yaitu

a. Mengamati Perilaku Peserta Didik

Langkah pertama yang dilakukan oleh guru adalah mengamati perilaku atau tindakan peserta didik. Di langkah ini, guru akan melihat jenis reward atau punishment sesuai dengan tindakan yang dilakukan oleh peserta didik. Hal ini diungkapkan oleh wakil kepala sekolah bidang kepeserta didikan. Beliau berkata:

Dimulai dari pengamatan tindakan yang sesuai dengan ketentuan reward dan punishment kemudian pemberian keputusan. Reward dan punishment salah satunya dilaksanakan bila guru berharap adanya hasil belajar yang lebih maksimal yang terbukti melalui hasil evaluasi. Hasil evaluasi dengan nilai yang baik diberi reward, dan yang belum maksimal diberi punishment. Untuk reward juga diberikan pada saat momen-momen tertentu misal pada saat ada perlombaan sedangkan punishment jika peserta didik tersebut melakukan pelanggaran atau kesalahan. ${ }^{14}$

Proses pemberian reward dan punishment dilakukan dengan mengamati dan mempertimbangkan bentuk perilaku yang dilakukan oleh peserta didik. Dalam proses pembelajaran berlangsung, harus memberikan namanya reward dan punishment untuk memberikan penilaian dan penghargaan kepada peserta didik, serta memberikan hukuman kepada peserta didik yang bermasalah, baik dalam proses pembejaran berlansung dan diluar proses pembelajaran.

b. Mendiskusikan Perencanaan Pemberian Reward dan Punishment

Pelibatan rekan atau kolega dalam pembahasan pemberian reward dan punishment sifatnya relatif mengingat pemberian reward dan punishment tergantung pada subjektivitas guru itu sendiri. Setiap guru memiliki mekanisme dan gaya yang berbeda dalam memberikan reward dan punishment.

Begitupula dengan guru yang mandiri dan berpengalaman akan mendesain konsep reward dan punishmentnya sendiri, sementara guru yang masih memerlukan bantuan rekan guru lain akan melibatkan rekan guru lain untuk membantunya dalam menentukan mekanisme reward dan punishment yang akan ia berikan kepada peserta didiknya. Bapak Suninggar mengatakan:

Terkadang kami diskusikan dengan guru lain. Biasa kami saling berdiskusi kalau bagaimana karakter itu peserta didik pada saat guru lain mengajar. Apakah beda dengan tingkah lakunya saat kita mengajar atau saat guru lain mengajar. Terkadang juga reward dan punishment itu tergantung dari guru mata pelajarannya tanpa mendiskusikannya dengan guru lain. Jadi kadang kami membicarakan dengan guru, kadang dengan orang tua peserta didik jika ada masalah peserta didik tersebut dalam pembelajaran. ${ }^{15}$

\footnotetext{
${ }^{14}$ Suninggar (53 Tahun) Guru PAI SMA Negeri 13 Makassar, Wawancara, Makassar 19 Juni 2019

${ }^{15}$ Mardiati (59 Tahun) Guru PAI SMA Negeri 13 Makassar, Wawancara, Makassar 18 Juni 
Hasil temuan di lapangan menunjukkan bahwa terdapat pola-pola yang berbeda yang dilakukan guru dalam melibatkan guru/orang lain dalam perencanaan reward dan punishment. Pertama, guru bidang studi dalam merencanakaan reward dan punishment akan melibatkan wali kelas dan guru BK yang tujuannya ialah untuk mengetahui kondisi dan karakter peserta didik serta batas kewajaran terkait dengan bentuk reward dan punishment yang akan diberikan. Kedua, dalam perencanaan reward dan punishment, khususnya punishment, guru akan mendiskusikan seorang peserta didik, sekelompok peserta didik, atau bahkan 1 kelas kepada rekan guru lain mengenai sikap dan perilaku yang dimunculkan oleh peserta didik tertentu pada waktu ia mengajar dan pada waktu guru lain mengajar. Tujuannya ialah untuk memastikan dan membandingkan perbedaan sikap dan perilaku yang dimunculkan oleh peserta didik yang terkait, yang selanjutnya akan dijadikan sebagai dasar pengambilan keputusan dalam pemberian reward ataupun punishment.

c. Mempertimbangkan Jenis Reward dan Punishment yang akan diberikan

Peneliti melihat beberapa aspek dalam pertimbangan pemberian reward dan punishment yaitu Pengetahuan, sikap dan perilaku peserta didik. Kemudian Pertimbangan dalam pemberian reward kepada peserta didik itu didasarkan kepada tinjauan ilmu pendidikan bahwa pemberian reward kepada peserta didik dapat meningkatkan motivasi mereka dalam belajar atau meningkat prestasi yang mereka raih. Sedangkan pemberian punishment didasarkan dengan pertimbangan bahwa agar perbuatan yang buruk yang mereka perbuat dapat mereka tinggalkan atau dijauhi.

Dalam memberikan reward dan punishment, guru juga melihat dampak yang akan ditimbulkan setelah peserta didik tersebut diberikan reward dan punishment. Hal ini diutarakan oleh Ibu Mardiati:

Motivasi peserta didik untuk lebih giat belajar, semangat belajar akan lebih meningkat sehingga hasil belajar meningkat. Tindakan yang dilakukan jika sesuai dengan hasil yang diinginkan dan bahkan melebihi harapan maka akan diberi reward sedangkan segala tindakan yang bertolak belakang dengan hasil akan di beri punishment. ${ }^{16}$

Begitupun halnya dengan pemberian punishment. Sebelum pemberian punishment, guru-guru juga perlu mempertimbangkan hal-hal tertentu, seperti faktor psikologis, lingkungan keluarga, serta kondisi peserta didik yang bersangkutan. ${ }^{17}$ punishment yang diberikan diupayakan agar bisa memperbaiki dan membentuk kebiasaan yang baik bagi peserta didik. Misalnya ketika peserta didik tidak mengerjakan tugas, maka hukuman yang diberikan diharapkan membuat peserta didik tersebut menjadi lebih giat lagi dalam mengerjakan tugas. Tujuan ialah agar Punishment yang diberikan memberikan dampak

\footnotetext{
${ }^{16}$ Mardiati (59 Tahun) Guru PAI SMA Negeri 13 Makassar, Wawancara, Makassar 18 Juni 2019

${ }^{17}$ Waode Hamlia (56 Tahun) Guru BK SMA Negeri 13 Makassar, Wawancara, Makassar 18 Juni 
positif terhadap peserta didik, yakni perubahan perilaku menjadi lebih baik, dan dapat meninggalkan perilaku ataupun kebiasaan buruk.

d. Menyimpan Rancangan Reward dan Punishment

Setiap informan menyatakan bahwa perencanaan atau hal-hal yang terkait dengan reward dan punishment tidak disebutkan dalam RPP (Rencana Pelaksanaan Pembelajaran) untuk bidang studi apapun. Sehingga guru harus menyimpan atau menulis rancangan reward dan punishmentnya yang akan diberlakukan pada saat pembelajaran. Mengenai reward dan punishment dalam RPP, Ibu Mardiati mengatakan:

Kalau tertulis tidak ada dalam RPP. Jadi nanti reward dan punishment tergantung dari pribadi guru-guru yang mengajar. Akan muncul dengan sendirinya saat pembelajaran berlangsung. Jadi bisa sebelum atau saat pembelajaran muncul itu reward dan punishment. ${ }^{18}$

Telah dijelaskan sebelumnya bahwa reward dan punishment tergantung pada guru yang bersangkutan dan pada kondisi tertentu. Tidak ada aturan baku yang mewajibkan guru untuk memberikan reward ataupun punishment, terkecuali dalam tata tertib sekolah. Pemberian reward akan muncul secara tidak disengaja, ketika peserta didik menunjukkan sikap, perilaku, atau hasil belajar yang baik seiring dengan inisiatif guru yang ingin memberikan reward. Begitupula dengan punishment, dimana peserta didik tidak direncanakan untuk melakukan pelanggaran sehingga diberikan punishment.

e. Mengumumkan kepada peserta didik mekanisme pemberian reward dan punishment yang akan diberlakukan

Pada dasarnya informasi mengenai adanya reward dan punishment telah diberitahukan guru kepada peserta didik. Hal ini dilakukan untuk memberikan motivasi kepada peserta didik. Pemberitahuan tentang adanya reward dan punishment dianggap dapat memancing peserta didik untuk belajar agar mendapatkan reward dan menjauhi pelanggaran agar tidak mendapatkan punishment. Ibu Mardiata mengatakan bahwa:

Membuat perencanaan, menyampaikan aturan main kepada peserta didik, tentang reward dan punishment. Memastikan materi yang diajarkan telah tuntas dan lengkap, pengumuman tentang pemberian reward dan punishment sebelum dilaksanakan. ${ }^{19}$

Selanjutnya mekanisme mengenai pemberian reward dan punishment diberitahukan kepada peserta didik agar peserta didik mengetahui sebab-sebab dan caracara yang mengasilkan reward dan menghasilkan punishment. Pemberitahuan mengenai mekaniseme tersebut berdampak pada adanya persiapan secara matang dari peserta didik. Aturan reward dan punishment bila di kelola secara teratur dan tersusun memberikan pengaruh terhadap keberhasilan pemberian reward dan punishment.

\footnotetext{
${ }^{18}$ Mardiati (59 Tahun) Guru PAI SMA Negeri 13 Makassar, Wawancara, Makassar 18 Juni 2019

${ }^{19}$ Mardiati (59 Tahun) Guru PAI SMA Negeri 13 Makassar, Wawancara, Makassar 18 Juni 2019
} 


\section{f. Memberlakukan Reward dan Punishment}

Pemberian reward dan punishment jangan hanya dipahami sebagai tindakan yang terjadi di dalam kelas. Mengingat proses pembelajaran, pembentukan karakter dapat dilakukan diluar kelas maka keberadaan reward dan punishment meliputi proses belajar di dalam dan di luar kelas. Aktifitas peserta didik di dalam kelas memungkinkan diberikan reward seperti peserta didik yang rajin mengerjakan tugas dan aktif berbicara dalam proses diskusi kelas, rewardnya dapat berupa pujian dan pemberian tambahan nilai. Sementara aktifitas peserta didik di luar kelas yang memungkinkan diberikan reward yaitu pada saat peserta didik sedang berjalan lalu di dapati sampah yang berserakan lalu ia memungutnya dan membuangnya di tempat sampah, dan di saat bersamaan perbuatan peserta didik tersebut disaksikan oleh salah satu guru.

Reward dan punishment diberlakukan di luar pembelajaran. Seperti yang diungkapkan oleh ibu Mardiati:

Jadi biasa saya lakukan sama anak wali ku. Misal bertemu di luar dan di dalam kelas kami biasa hanya mengingatkan kepada anak wali kita. Dilakukan juga di luar pembelajaran. Seperti yang berkaitan dengan keikutsertaan dalam suatu lomba atau yang berkaitan dengan pelanggaran yang dilakukan di lingkungan sekolah. Jadi hal ini dilakukan dan diterapkan karena bagian dari penialian. ${ }^{20}$

Di dalam pembelajaran, faktor yang menjadi dasar pemberian reward dan punishment sudah cukup jelas, yakni pengetahuan, sikap dan perilaku peserta didik terhadap pembelajaran tertentu. Sedangkan di luar pembelajaran, sikap dan perilaku merupakan 2 aspek yang ditekankan, dimana sikap dan perilaku peserta didik di luar pembelajaran akan dinilai kemudian diakumulasikan ke dalam hasil belajar peserta didik secara keseluruhan.

\section{Pelaksanaan Pemberiaan Reward dan Punishment di SMA Negeri 13 Makassar}

Pelaksanaan reward di dalam kelas sangat sering peneliti temukan. Setidaknya reward yang paling sering diberikan pendidik adalah pujian, sanjungan, tepuk tangan dan penambahan nilai. Mengenai proses pelaksanaan reward di dalam kelas yang dilakukan ketiga guru pendidikan agama Islam, terdapat persamaan dan perbedaan. Persamaan dan perbedaan tersebut akan peneliti uruaikan berdasarkan tahapan-tahapan proses pembelajaran yang berlangsung dalam kelas.

Pertama, guru mengucapkan salam sebelum masuk ke dalam kelas. Guru mengucapkannya pada saat mengetuk pintu. Selanjutnya salam guru di jawab oleh peserta didik. Guru kemudian duduk di tempat duduknya dan menginstruksikan kepada peserta didik supaya duduk di tempat duduknya masing-masing, tidak ribut dan memerintahkan mempersiapkan alat tulis menulis. Selanjutnya guru mempersilahkan ketua kelas untuk memimpin doa.

${ }^{20}$ Mardiati (59 Tahun) Guru PAI SMA Negeri 13 Makassar, Wawancara, Makassar 18 Juni 2019 
Kedua, ketika situasi kelas telah kondusif, guru kembali memberi salam untuk yang kedua kalinya dan mengabsen peserta didik sambil mengamati peserta didiknya. Sesekali guru bertanya kepada peserta didik, seperti “Abid Rizik, apakah tugas yang diperintahkan Ibu sudah di selesaikan", seperti inilah bentuk sapaan yang diberikan guru saat memberi absen. Akan tetapi, tidak semua peserta didik diberikan sapaan seperti itu, hanya beberapa saja yang di anggap guru memiliki urusan dengannya. Peneliti pernah menemukan guru memberikan punishment kepada peserta didik saat guru memberikan absen. Ada guru yang biasa memberikan teguran saat proses absen berlangsung. Bentuk Punishment yang biasa diberikan yaitu teguran sambil memukul meja. Sementara ada juga guru tidak sering menegur saat proses absen berjalan, dan saat menegur hanya sebatas menegur tanpa memukul meja. Faktor yang menyebabkan pemberian punishment tersebut karena pada saat nama peserta didik disebutkan, peserta didik yang bersangkutan tidak mendengar, tidak menjawab absen dan tidak mengangkat tangan disebabkan peserta didik yang bersangkutan sedang asyik bercerita dengan temannya atau sedang bermain-main dengan temannya. Dengan demikian, guru memiliki persamaan bentuk punishment saat memberi absen lalu ada peserta didik yang tidak menyahut saat namanya disebutkan. Hanya saja ada guru yang memberi tindakan tambahan yakni sambil memukul meja .

Ketiga, guru menyampaikan tujuan pembelajatan. Pada tahap ini peneliti tidak pernah menemukan adanya reward dan punishment yang diberikan ketiga guru pendidikan agama Islam.

Keempat, sebelum guru menjelaskan materi pembelajaran yang ingin dibahas, guru terlebih dahulu bertanya-bertanya kepada peserta didik mengenai materi sebelumnya yang telah dibahas. Pada saat peneliti mengamati jalannya proses pembelajaran, materi yang dibawakan adalah materi tentang memahami makna Asmaul Husna, lalu guru bertanya kepada peserta didik tentang pengertian Asmaul Husna yang merupakan materi pada pertemuan sebelumnya. Pada tahap ini, terdapat 3 peserta didik yang menjawab dengar benar pertanyaan dari guru. Reward yang diberikan guru kepada peserta didik yang menjawab adalah pujian seperti, "Jawaban yang bagus" sambil memberikan acungan jempol. Reward dengan bentuk ini diberikan ketiga guru pendidikan agama, sebagaimana hasil pengamatan peneliti.

Kelima, guru lalu menghubungkan materi yang dibahas dengan materi sebelumnya. Kemudian guru menjelaskan materi yang dibahas pada hari itu. Pada proses ini, peneliti beberapa kali melihat peserta didik yang ribut dan pada saat itu langsung mendapatkan teguran dari guru sebagai bentuk punihsment. Untuk menangani peserta didik yang ribut disaat guru menjelaskan materi pembelajaran, guru menegur dan memarahi peserta didik yang ribut. Sementara itu, ada juga guru menghampiri peserta didik yang ribut. Kemudian guru lain ketika melihat Peserta didik yang ribut saat menjelaskan materi pembelajaran maka diberi punishment dengan cara menggertak. Ketiga guru sama-sama memberikan punishment apabila terdapat peserta didik yang ribut di saat materi pembelajaran sedang 
disampaikan. Hanya saja, setiap guru memiliki cara yang berbeda dalam memberikan punisment.

Keenam, guru mempersilahkan kepada peserta didik untuk bertanya mengenai materi yang dibahas jika masih ada yang kurang dipahami. Bila tidak ada peserta didik yang bertanya, guru yang memberikan pertanyaan kepada peserta didik. Bagi peserta didik yang berhasil menjawab pertanyaan dengan benar, guru memberikan reward. Reward yang diberikan guru kepada peserta didik yang berhasil menjawab pertanyaan berbeda-beda. Guru biasa memberi reward berupa hadiah yakni amplop yang berisi gulagula. Reward yang dalam bentuk lain diberikan kepada peserta didik yang berhasil menjawab pertanyaan berupa pujian dengan mengatakan "Jawaban yang bagus". Sementara ada juga reward yang diberikan kepada peserta didik yang berhasil menjawab pertanyaan dengan benar adalah sanjungan sambil memberikan acungan jempol.

Ketujuh. Pada tahap ini guru menyimpulkam materi pembelajaran dan memberi tugas kepada peserta didik untuk dikerjakan dirumah. Guru lalu menyampaikan kepada peserta didik, bahwa jika ada peserta didik yang tidak menyelesaikan tugasnya pekan depan, akan diberikan hukuman berupa berdiri di depan sambil disaksikan peserta didik yang lain dan hukuman berupa hafalan ayat al-Qur'an dan Hadis. Guru memberikan ancaman hukumaan berupa berdiri di depan teman kelas, dan menghafal ayat-ayat alQur;an dan hadits. Setelah memberikan tugas, guru menutup proses pembelajaran.

Dengan demikian, berdasarkan hasil pengamatan peneliti, terdapat tahap-tahap dalam pembelajaran di kelas yang rawan bagi peserta didik diberikan teguran seperti pada tahap kedua saat guru mengabsen peserta didik namun ada peserta didik yang tidak memperhatikan atau tidak mendengar namanya disebut. Selain itu, peneliti juga melihat bahwa pada tahap kelima yakni pada saat guru menjelaskan materi pembelajaran, sering ditemukan peserta didik yang bermain-main, ribut dan tidak memperhatikan materi yang dijelaskan guru. Sehingga pada tahap kelima tersebut termasuk tahap yang rawan bagi peserta didik diberikan punishment.

Adapun pemberian reward, maka biasa terjadi pada tahap keenam yakni pada sesi tanya jawab antara guru dengan peserta didik. Bagi peserta didik yang berhasil menjawab dengan benar diberikan reward sementara bagi yang tidak menjawab dengan benar tidak diberikan punishment dan tidak pula diberikan reward.

\section{Evaluasi Pemberiaan Reward dan Punishment di SMA Negeri 13 Makassar}

Untuk mengetahui tingkat keberhasilan reward dapat dilihat melalui indikatorindikator yang menunjukkan adanya peningkatan yang sejalan dan berbanding lurus antara motivasi dan capaian belajar peserta didik. Ketika terjadi peningkatan pada hasil belajar pada peserta didik yang telah diberikan reward, maka disimpulkan bahwa reward yang diberikan berhasil.

Sebelum memberikan reward, guru telah menentukan tujuan apa yang hendak dicapai dari pemberian reward tersebut. Tujuan tersebut biasanya dikaitkan dengan tujuan pembelajaran, serta konsistensi sikap dan perilaku positif. Ketika peserta didik 
diminta untuk mengerjakan tugas untuk memperoleh reward dan ia menyelesaikannya tugas tersebut dengan baik, maka tujuan dari reward tersebut dapat dikatakan berhasil.

Untuk mengetahui tingkat keberhasilan punishment dapat diketahui melalui indikator-indikator yang menunjukkan adanya perubahan pada perilaku peserta didik kepada perubahan positif setelah diberikan punishment. Keberhasilan pertama yang dilihat ialah ketika peserta didik diberikan tugas tambahan. Apabila ia mampu menyelesaikan tugas tersebut dengan baik, maka punishment yang diberikan memberikan efek positif.

Keberhasilan dari punishment juga dilihat pada munculnya kesadaran serta tidak adanya pengulangan pada pelanggaran yang sama. Terdapat pula perubahan pada sikap, pengetahuan dan keterampilannya. Berbeda dengan guru bidang studi dan wali kelas, Guru BK sendiri lebih menekankan pada kedisiplinan dimana ketika peserta didik menunjukkan sikap disiplin, maka disimpulkan bahwa Punishment yang diberikan memberikan hasil positif pada peserta didik.

Keberhasilan dari pemberian punishment juga dapat dilihat pada perubahan sikap peserta didik setelah lulus. Namun indikator utama ialah terjadi perubahan pada sikap, perilaku, dan pengetahuan peserta didik ke arah yang lebih baik. Tidak semua reward yang diberikan kepada peserta didik berlaku efektif. Sehingga guru perlu mengganti atau mengembangkan model reward yang lain. Misalnya ketika peserta didik sudah jenuh dengan pemberian pujian lisan (pujian lisan tidak memberi kesan positif kepada peserta didik), maka reward akan ditingkatkan pada pemberian nilai tambahan.

Jika peserta didik tidak lagi melakukan kesalah yang sama secara berulang-ulang. Pada dasarnya tidak jauh berbeda dengan pemberian reward. Sebab pemberian reward dan punishment dimaksudkan untuk merubah perilaku peserta didik menuju perubahan yang lebih baik yang dapat dilakukan dengan pengamatan sehari-hari. Yang sebelumnya malas belajar menjadi rajin belajar dan lain-lain. ${ }^{21}$

Selain itu, terkadang target yang diberikan untuk memperoleh reward cukup sulit sehingga guru memberikan layanan bimbingan khusus kepada peserta didik yang bersangkutan. Pada pembahasan bentuk dan pelaksanaan pemberian punishment telah dijelaskan tingkatan bentuk hukuman yang menyesuaikan dengan tingkat pelanggaran yang dilakukan oleh peserta didik.

Alternatif lain yang dilakukan oleh salah satu guru di SMA Negeri 13 Makassar ialah dengan memberikan ancaman berupa penilaian buruk yang bagi seluruh peserta didik dalam satu kelas, sehingga mencegah peserta didik bermalas-malasan dan kompak dalam belajar.

Hasil temuan menunjukkan bahwa pada umumnya reward dan punishment berhasil diterapkan, dilihat dari indikator-indikator yang disebutkan sebelumnya. Adapun reward

${ }^{21}$ Waode Hamlia (56 Tahun) Guru BK SMA Negeri 13 Makassar, Wawancara, Makassar 18 Juni 
dan punishment yang tidak efektif diupayakan untuk disempurnakan melalui dengan perbaikan-perbaikan pada bentuk reward atau punishment. Melalui pemberian reward dan punishment, guru pun dapat mengetahui lebih dalam tentang karakter masing-masing peserta didiknya yang memudahkan guru untuk merencanakan reward dan punishment yang cocok untuk masing-masing peserta didik ketika diperlukan.

\section{B. Faktor Pendukung dan Penghambat pada Proses Pemberian Reward dan Punishment dalam Pembelajaran PAI di SMA Negeri 13 Makassar}

\section{Pendukung Reward}

Terdapat beberapa hal yang menjadi pendukung pemberian reward yaitu
a) Kewenangan Mengelola Reward
b) Dukungan Sekolah
c) Dukungan Orang Tua/Wali
d) Motivasi Peserta Didik

\section{Penghambat Reward}

Pemberian reward tidak selamanya diterima positif dan memberikan efek penguatan kepada peserta didik. Dalam pemberiannya, masih ditemukan peserta didik yang tidak mempedulikan adanya reward. Maka terkadang ada bentuk reward yang tidak efektif diberikan untuk peserta didik tertentu. Kemudian dalam penerapannya, apabila dikaitkan dengan pembelajaran dengan tingkat kesukaran yang tinggi, terkadang sulit untuk dicapai oleh peserta didik, sehingga kadang-kadang reward yang ditawarkan tidak mampu didapatkan oleh peserta didik. Tingkat kecerdasan dan perbedaan kemampuan dalam memahami pelajaran juga merupakan salah satu faktor penghambat reward. Hanya peserta didik yang aktif yang akan terus menerus memperoleh reward, sementara yang pasif tidak sama sekali. Oleh karena itu, guru memerlukan strategi lain yang memungkinkan setiap peserta didiknya aktif dalam pelajaran.

Adapun Faktor Penghambat Reward yaitu
a) Biaya
b) Lingkungan
c) Tingkat Kemampuan Peserta Didik yang Berbeda

\section{Solusi dari Faktor Penghambat Reward}

Adapun solusi yang bisa digunakan untuk mengatasi faktor penghambat di atas yaitu

a) Menggunakan reward dalam bentuk yang lain.

b) Memberikan perhatian khusus kepada peserta didik.

c) Memberikan bimbingan khusus

\section{Pendukung Punishment}
a) Dukungan Sekolah
b) Dukungan Orang Tua/Wali
c) Kesadaran Peserta Didik

5. Penghambat Punishment

a) Kurangnya Perhatian Orang Tua/Wali

b) Adanya HAM 
c) Karakter Peserta Didik

\section{Solusi dari Penghambat Punishment}

Adapun solusi yang bisa digunakan untuk mengatasi faktor penghambat di atas yaitu

a) Memanggil orang tua peserta didik

b) Musyawarah

c) Memberikan bimbingan

C. Hasil Proses Pemberian Reward dan Punishment dalam Pembelajaran PAI di SMA Negeri 13 Makassar

Pemberian reward dan punishment bertujuan untuk meningkatkan kualitas peserta didik. Reward membawa peserta didik pada keadaan untuk semakin meningkatkan potensi-potensi dalam dirinya seperti peningkatan prestasi belajar, menambah pengetahuan, memacu kreativitas, serta semakin memperbaiki kontrol diri. Adapun punishment pada dasarnya bertujuan untuk memperbaiki pola pikir, tingkah laku, kebiasaan serta kepribadian peserta didik yang dinilai tidak sejalan dengan cita-cita pendidikan nasional. Dampak pemberian reward di SMA Negeri 13 Makassar sebagaimana yang peneliti temukan yakni bertambahnya motivasi belajar peserta didik. Sementara pemberian punishment di SMA Negeri 13 Makassar dianggap memberikan efek jera bagi peserta didik sehingga tidak mengulang kembali kesalahan atau pelanggaran yang pernah dilakukan.

Pada pemberian reward dan punihsment, guru-guru di SMA Negeri 13 Makassar memiliki caranya masing-masing. Jenis keberhasilan serta kesalahan peserta didik menjadi alat ukur dalam menentukan jenis reward dan punishment yang diberikan. Berikut ini akan di uraikan hasil analisa peneliti mengenai hasil proses pemberian reward dan punishment di SMA Negeri 13 Makassar, dengan melihat metode-metode yang dilakukan guru dalam menentukan reward dan punishment berdasarkan hasil penilaian masing-masing guru, serta menganalisa faktor-faktor yang membantu jalannya pemberian reward dan punishment, begitula pula faktor yang menghambat sehingga pemberian reward dan punisment mendapat kendala. Dengan demikian hasil pemberian reward dan punisment dapat diketahui. Hasil yang di maksud disini adalah hasil yang didapatkan peserta didik sebagai objek yang diberikan reward dan punishment.

1. Pemberian reward dan punishment untuk meningkatkan motivasi belajar peserta didik.

Pemberian reward dan punihsment sepenuhnya berada dalam wewenang guru. Guru bisa memilih jenis reward dan punishment yang diinginkan berdasarkan keinginan masing-masing guru namun tetap memperhatikan tata tertib serta aturan ketika menerapkannya.

Untuk meningkatkan motivasi belajar peserta didik dalam kelas, maka peserta didik yang mampu menjawab pertanyaan guru dalam kelas serta berhasil menyelesaikan tugas yang diberikan dengan cepat, akan diberikan pujian atau meminta kepada seluruh peserta didik yang berada dalam kelas agar memberi tepuk tangan. Hal ini akan memicu semangat peserta didik dalam proses belajar. Terutama peserta didik yang diberi pujian lisan dan 
tepuk tangan dari peserta didik lain akan merasakan kebahagian. Sensasi yang dirasakan akan menjadi pemicu bagi peserta didik untuk kembali berusaha menjawab pertanyaan guru ataupun berusaha menyelesaikan tugas yang diberikan dilain waktu.

Akan tetapi, setiap perserta didik ternyata memiliki karakteristik yang berbeda. Tidak semua peserta didik mengharapkan pujian. Bahkan tidak semua peserta didik senang dipuji. Hal ini membuat peserta didik tidak berambisi mendapatkan pujian serta tepuk tangan. Ia lebih memilih memberi tepuk tangan kepada peserta didik lain dibandingkan diberi tepuk tangan.

Pemberian reward berupa pujian lisan kepada peserta didik untuk meningkatkan semangat belajar peserta didik, dipandang berhasil oleh guru terhadap sebahagian peserta didik. Hal ini sebenarnya mampu menambah keakraban serta membangun relasi antara peserta didik dengan gurunya. Dengan demikian, dalam beberapa kesempatan, termasuk aktivitas diluar proses pembelajaran dalam kelas, guru mampu memberikan pujian yang berifat motivasi kepada peserta didik untuk tetap semangat mengikuti pembelajaran dalam kelas. Sebagai sosok motivator, guru dituntut memiliki gaya bahasa yang disukai peserta didik dan juga mudah dipahami. Peserta didik akan dengan mudah meresapi maksud guru yang menginginkan peserta didik dalam porses belajar agar aktif dan memperhatikan materi-materi yang disampaikan.

\section{Pemberian reward dan punishment untuk meningkatkan prestasi belajar peserta didik}

Lahirnya peserta didik yang berprestasi tentu memberi kebanggan tersendiri bagi guru yang mengajarnya. Pihak sekolah juga merasa bangga bila peserta didik-siswinya berprestasi. Keberadaan mereka kelak bisa membantu mengharumkan nama baik sekolah dalam kompetisi-kompetisi antara sekolah dalam skala kabupaten hingga skala nasional.

Reward kepada peserta didik berprestasi biasanya berupa hadiah seperti buku, pulpen hingga piagam. Bila di uangkan, mungkin tidak seberapa tetapi pemberian reward seperti ini menunjukkan dedikasi seorang guru kepada muridnya. Peserta didik juga tidak melihat pemberian dari guru sebagai hadiah murahan tetapi tersirat pesan positif kepada peserta didik agar mempertahankan prestasinya. Pesan positif ini akan memotivasi peserta didik untuk terus belajar. Dengan belajar prestasi bisa dipertahankan.

Kendala guru dalam memberikan reward terletak pada biaya. Guru kemudian berinisiatif agar tetap memberikan reward berupa benda pakai yang bermanfaat. Walaupun harganya murah tapi diharapkan mampu menghadirkan kesan positif kepada peserta didik yang berprestasi.

Misalkan, peserta didik berprestasi diberi reward beberapa buah buku dan pulpen atas prestasi yang diraihnya. Ditahun ajaran selanjutnya, buku dan pulpen yang dihadiahkan kepada peserta didik yang berprestasi akan digunakan untuk sekolah. Sehingga peserta didik tidak lagi memberatkan orang tuanya untuk membelikan buku dan pulpen. Dalam hal ini guru telah sedikit membantu memenuhi kebutuhan peserta didik yang merupakan tanggung jawab orang tua peserta didik. Selain itu, sesekali buku dan 
pulpen yang dipakai peserta didik mengingatkan peserta didik bahwa buku dan pulpen tersebut adalah hadiah dari gurunya. Rasa senang dan bahagia peserta didik karena buku dan pulpen yang digunakannya untuk belajar adalah pemberian dari gurunya, berpotensi merangsang peserta didik untuk mempertahankan prestasinya dan semakin meningkatkan prestasinya.

Peserta didik lalu mengetahui bahwa setiap prestasi yang diraihnya akan mendatangkan keuntungan, seperti mendapatkan hadiah berupa alat tulis menulis. Dengan demikian, peserta didik akan menjadikan prestasi sebagai target yang harus diraih dalam proses belajarnya. Membiasakan pemberian hadiah terhadap peserta didik yang berprestasi akan menghasilkan stimulus yang bisa mendorong peserta didik untuk berprestasi kembali. Keadaan ini sangat sesuai dengan teori belajar yang di ungkapkan Ivan Petrovich Pavlov berkenaan dengan Law of Respondent Conditioning atau hukum pembiasaan yang dituntut. Cukup dengan membiasakan peserta didik merasa senang setiap kali ia berprestasi maka setiap saat pula peserta didik akan berusaha untuk berprestasi.

\section{Pemberian reward dan punishment untuk memperbaiki tingkah laku peserta didik.}

Pemberian reward dan punishment tidak hanya berlangsung di dalam kelas, melainkan diterapkan pula diluar kelas. Interaksi antara guru dan peserta didik diluar kelas tidak sekaku saat di dalam kelas. Hal ini dapat melonggarkan usaha guru untuk membentuk perilaku terpuji pada peserta didik. Di akui oleh para guru, bahwa pemberian reward dan punishment juga diberlakukan diluar kelas atau di jam istrahat.

Namun apabila pemberian reward dan punishment dilakukan diluar kelas, seperti pada saat peserta didik sedang berjalan atau duduk, dan pada saat itu ia sedang sendiri. Pada kondisi seperti ini seorang guru bisa memberikan teguran kepada peserta didik terhadap kesalahan yang sebelumnya pernah dilakukan. Teguran lisan menjadi langkah awal untuk memperbaiki perilaku peserta didik. Misalkan peserta didik sering ribut dan mengganggu temannya dalam kelas saat proses pembelajaran sedang berlangsung. Guru tidak secara langsung menegurnya dalam kelas melainkan mencari momen di luar kelas untuk berbicara dengan menasehati peserta didik agar perilaku-perilakunya yang kurang terpuji, yang dapat merusak suasana kelas yang mulanya kondusif bisa ia rubah dan tinggalkan.

Dalam teori belajar behaviorisme yang berhubungan dengan perilaku, dikenal teori conetionisme yang dikembangkan oleh Edward Lee Thorndike. Teori ini mengajarkan bahwa setiap mahkluk hidup dalam tingkah lakunya adalah hasil dari stimulus dan respon. Penerapannya di SMA Negeri 13 Makassar terhadap peserta didik yang melanggar bertujuan untuk mengubah perilaku peserta didik yang tidak baik dengan memberikan ganjaran berupa hal-hal yang tidak disukai. Perubahan perilaku sebagai hasil belajar terangkum dalam tiga hukum dalam teori ini. 
a. Law Of Readiness atau Hukum Kesiapan

b. Law Of Exercise atau Hukum Latihan

c. Law Of Effect atau Hukum Hasil

Pada bagian ke 3 yakni Law Of Effect atau hukum hasil telah diterapkan oleh guruguru di SMA Negeri 13 Makassar dalam rangka memberi dampak tidak menyenangkan kepada peserta didik yang melanggar. Law Of Effect atau hukum hasil memberi gambaran bahwasanya perilaku yang disertai akibat yang menyenangkan akan cenderung dipertahankan atau diulang kembali diwaktu tertentu sementara perilaku yang diikuti akibat yang tidak menyenangkan akan dihentikan dan tidak di ulang kembali.

Pemberian surat panggilan terhadap orang tua peserta didik yang melakukan pelanggaran berat membuat peserta didik merasa tidak nyaman dan tidak suka apabila orang tuanya datang ke sekeloh lalu bertemu dengan gurunya. Bisa saja timbul rasa malu dari hati peserta didik karena perbuatannya membuat orang tuanya harus datang ke sekolah. Peserta didik pun merasa bahwa orang tuanya juga akan malu apabila mengetahui anaknya melakukan perbuatan tercela seperti mencuri barang temannya. Rasa tidak nyaman yang dirasakan oleh peserta didik yang melanggar akan membuatnya tidak lagi mengulangi perbuatan tersebut.

Dengan demikian, bila kembali pada teori conetionisme yang merupakan bagian dari teori behaviorisme, maka guru SMA Negeri 13 Makassar telah menerapkan teori ini untuk membentuk perilaku peserta didik sesuai dengan harapan guru. Hasilnya peserta didik tidak lagi melakukan tindakan pencurian dilingkungan sekolah.

Peserta didik berhenti mencuri karena telah merasakan akibat yang tidak menyenangkan saat kedapatan mencuri. Rasa tidak nyaman inilah yang mendorong peserta didik tidak lagi mengulang perbuatannya. Sebaliknya peserta didik akan cenderung melakukan dan mengulang perbuatan-perbuatan yang mengakibatkan dirinya merasa senang, seperti mendapatkan pujian atau poin apabila memungut sampah yang berada di pekaranan sekolah.

Misi guru untuk menjaga perilaku-perilaku peserta yang sudah baik agar tetap dipertahankan dibuktikan dengan memberi reward kepada peserta didik sebagai stimulusnya. Responya akan memicu pada pengulangan perilaku terhadap stimulus yang menyenangkan tersebut.

Dalam prakteknya, reward yang diberikan untuk mempertahankan perilaku baik peserta didik dibuat beragam. Kebutuhan atau ketertarikan peserta didik terhadap suatu hal berbeda, sehingga berbeda pula hal-hal yang bisa menyenangkan hati masing-masig peserta didik. Apabila peserta didik melakukan perilaku terpuji kemudian diberikan reward, namun ternyata tidak terlalu menyenangkan hati peserta didik atau peserta didik cenderung cuek terhadap reward yang ia dapatkan maka guru akan mencari alternatif lain sebagai reward bagi peserta didik. Misalkan reward kepada peserta didik yang berperilaku baik berupa kata-kata positif, maka akan ditambah dengan pemberian katakata positif beserta sebuah hadiah untuk menguatkan stimulusnya. Semakin kuat dan 
berkesan stimulus yang dirasakan peserta didik makan akan semakin kuat pula perilaku yang diharapkan lahir dari stimulus tersebut.

\section{V.SIMPULAN}

Proses Pemberian reward di SMA Negeri 13 Makassar kebanyakan dalam bentuk pujian lisan dan penambahan nilai, sedangkan untuk Punishment bentuknya bervariasi, beberapa punishment diberikan dalam bentuk penambahan tugas, pemberian teguran, hingga pelibatan orang tua (wali). Namun kebanyakan bentuk punishment dilakukan dengan penambahan tugas.

Faktor pendukung reward yaitu kewenangan guru dalam mengelola reward, Adanya dukungan pihak Sekolah, Adanya dukungan Orang Tua (Wali) dan adanya motivasi peserta didik. Adapun faktor pendukung Punishmnet yaitu adanya dukungan pihak Sekolah, adanya dukungan orang tua (wali) dan kesadaran peserta didik.

Solusi penghambat pelaksanaan reward yaitu menggunakan reward dalam bentuk lain, memberikan perhatian khusus kepada peserta didik dan memberikan bimbingan khusus. Dan Solusi penghambat pelaksanaan punishment yaitu memanggil orang tua peserta didik, musyawarah dan memberikan bimbingan.

\section{DAFTAR PUSTAKA}

Alang, Sattu. Guru yang Profesional Memiliki Kecerdasan Intelektual, Emosional dan Spritual. Jurnal Al-Irsyad Al-Nafs Vol. 1, no. 1 Tahun 2015.

Creswell, John W. Research Design Pendekatan Kualitatif, Kuantitatif dan Mixed. Cet. VI; Yogyakarta: Pustaka Pelajar, 2017.

Echols, John M. dan Hasan Shadily. Kamus Inggris Indonesia. Jakarta: Gramedia, 2014. Kusyairy, Umy dan Sulkipli. Meningkatkan Hasil Belajar Peserta Didik Melalui Pemberian Reward And Punishment. Jurnal Pendidikan Fisika Vol. 6 no. 2 Tahun 2018

Kementerian Agama R.I. Al-Qur`an dan Terjemahnya. Bandung: PT. Sygma Examedia Arkanleema Tahun 2017.

Purnomo, Halim dan Husnul Khotimah Abdi. Model Reward dan Punishment Perspektif Pendidikan Islam. Cet. II; Yogyakarta: Deepublish Publisher, 2013.

Purwanto, M. Ngalim. Psikologi Pendidikan. Cet. XXVII; Bandung: PT. Remaja Rosdakarya, 2014.

Qadar, M. Ali Qadar. Metode Hukuman dalam Pendidikan Islam. Tesis: Pascasarjana UIN Alauddin Makassar. 
Rahman, Ulfiani dkk. Pengaruh Kecerdasan Matematik Logis dan Kecerdasan Spasial terhadap Hasil Belajar Matematika Peserta didik Kelas VII SMP Negeri 4 Sungguminasa Kabupaten Gowa. Jurnal MAPAN Vol. 3, no. 2 Tahun 2015.

Santrock, John W. Psikologi Pendidikan. Cet. VI; Jakarta: Kencana, 2015.

Sugiyono. Metode Penelitian Pendidikan Pendekatan Kuantitatif, Kualitatif dan R\&D. Cet. XXVI; Bandung: Alfabeta, 2017.

Sukmadinata, Syaodih. Metode Penelitian Pendidikan. Cet. VIII; Bandung: PT. Remaja Rosdakarya, 2012.

Sulyadi. Upaya Meningkatkan Disiplin Guru Dalam Kehadiran Mengajar Dikelas Melalui Penerapan Reward And Punishment di SDN 03 Simpang Kabupaten Pesisir Selatan. Jurnal Manajemen Pendidikan Vol. 3 no. 2 Tahun 2018.

Suyono dan Hariyanto. Implementasi Belajar dan Pembelajaran. Cet. I; Bandung: PT. Remaja Rosdakarya, 2015.

Syah, Muhibbin. Psikologi Belajar. Cet. XIV; Jakarta: PT. Rajagrafindo Persada, 2015.

Tim Penyusun Pedoman Penulisan Karya Ilmiah. Pedoman Penulisan Karya Tulis Ilmiah; Makalah, Skripsi, Tesis, Disertasi dan Laporan Penelitian. Cet I; Makassar: Alauddin Press, 2013.

Undang-Undang SISDIKNAS 2003. Undang-undang RI No.20 Tahun 2003 tentang Sistem Pendidikan Nasional. Cet VII; Jakarta: Sinar Grafika, 2016.

Usman, Moh Uzer. Menjadi Guru Profesional. Bandung: PT Remaja Rosdakarya, 2000.

Yana, Dewi dkk. Pemberian Reward and Punishment sebagai Upaya Meningkatkan Prestasi Peserta didik Kelas V di SDN 15 Lhokseumawe. Jurnal Ilmiah FKIP Unsyiah Vol I no. 2 Tahun 2016.

Yunus, Noor Mu'minin. Pengaruh Motivasi Belajar dan Konsep Diri terhadap Hasil Belajar Pendidikan Agama Islam Peserta Didik di SMP Negeri 1 Tanete Riaja Kabupaten Barru. Tesis: Pascasarjana UIN Alauddin Makassar.

Zainal, Veithzal Rivai dan Fauzi Bahar. Islamic Education Management. Cet. I; Jakarta: PT. Rajagrafindo Persada, 2013. 